\title{
Et pedagogisk opplegg gir studenter bedre forståelse av sykepleierrollen
}

\section{Studentene tilegnet seg kunnskap om emnet}

«Sykepleierens pedagogiske og veiledende funksjon» gjennom aktive læringsopplegg både individuelt og $\mathrm{i}$ fellesskap.

\section{Helene Hoemsnes}

Høgskolelektor

Avdeling for helse- og sosialfag, Høgskolen i Molde

\section{Kari Westad Hauge}

\section{Dosent}

Avdeling for helse- og sosialfag, Høgskolen i Molde

Læringsutbytte

Pedagogikk

\section{Hovedbudskap}

Hensikten med denne artikkelen er å beskrive det pedagogiske opplegget for emnet «Sykepleierens pedagogiske og veiledende funksjon» og diskutere i hvilken grad dette tilrettelegger for studentenes læringsutbytte. Studentene fikk ressursforelesning knyttet til planlegging og gjennomføring av undervisning. Artikkelen omhandler den veiledende funksjonen. 
Sykepleiere har ansvar for å informere, undervise og veilede pasienter og pårørende. Ifølge Ottawa-charteret (1) skal det være søkelys på å fremme helse og tilrettelegge for maktomfordeling der fagpersonen gir makt til pasienten eller brukeren av helsetjenesten.

Ifølge forskrift om nasjonal retningslinje for sykepleierutdanning (2) skal utdanningen sikre at kandidater har kunnskap om relevante undervisnings- og veiledningsmetoder ( $\$ 7 \mathrm{e}$ ) og metoder for brukermedvirkning ( $\$ 16 \mathrm{~b}$ ).

Videre forventes det at kandidaten kan anvende kunnskap om lærings-, mestringsog endringsprosesser i veiledning og undervisning ( $\$ 8 \mathrm{~b}$ ) og anvende veiledningskompetanse ( $\$ 8 \mathrm{c})$.

Da vi skulle utarbeide en ny studieplan på bakgrunn av den nye retningslinjen, valgte vi å opprette emnet «Sykepleierens pedagogiske og veiledende funksjon» på tre studiepoeng. Emnet ble lagt til andre studieår.

\section{Å lære er å oppdage}

Med ulike begrunnelser la vi til rette for at studentene skulle få teoretisk kunnskap og praktisk erfaring giennom vårt pedagogiske opplegg. Ryle (3) hevder at forholdet mellom teoretisk og praktisk kunnskap, «knowing that» og «knowing how», er sentralt i profesjonskvalifisering.

Grimen (4) bruker praktiske synteser for å betegne profesjoners sammensatte og mangfoldige kunnskapsbase og for å understreke at de viktigste sammenhengene i kunnskapsbasen er praktiske.

\section{«Med ulike begrunnelser la vi til rette for at studentene skulle få teoretisk kunnskap og praktisk erfaring gjennom vårt pedagogiske opplegg.»}

Han beskriver at en viktig del av profesjonsutøverens kunnskap kjennetegnes ved at kunnskapens form og innhold må læres gjennom personlig, praktisk erfaring (4). Konfluent pedagogikk representerer en undervisningsmetode der både følelsesmessige, intellektuelle og psykomotoriske aspekter er integrert i lærings- og undervisningsprosessen (5).

Det betyr at studenten også skal få kontakt med følelsene og kroppsreaksjonene som temaet, og arbeidet med det, vekker i ham. Et grunnleggende prinsipp innen konfluent pedagogikk er at å lære er å oppdage. 
Erfaringslæring brukes ofte som betegnelse på læresituasjoner hvor prinsippet «å lære er å oppdage» står i sentrum. Det å oppdage er en helt subjektiv prosess - det er bare jeg som kan oppdage for meg (5).

\section{Teorier skiller mellom individsentrert og kontekstuell posisjon}

Læringsteoretiske posisjoner skiller mellom individsentrert (kognitiv) og kontekstuell (situert) posisjon. Individsentrert posisjon belyser individets tenkning og forståelse samt utvikling som en individuell aktør.

Kontekstuell posisjon belyser samhandling og læringskontekstens betydning (6). Illeris (7) ser kognitive og kontekstuelle perspektiver som delvis overlappende og beskriver at læring kan forstås som to prosesser og tre dimensjoner (8).

De to prosessene er samspillsprosesser som skjer mellom individet og omgivelsene, og individets tilegnelsesprosess der impulsene fra samspillet bearbeides og tilegnes. Tilegnelsesprosessen omfatter både et innhold og en drivkraft, noe som gjør at læringen alltid har både et subjekt og et objekt; det er alltid noen som lærer noe.

De tre dimensjonene er innholds-, drivkrafts- og samspillsdimensjonen. Illeris' grunnleggende tese er at læringens to prosesser og tre dimensjoner inngår i enhver læreprosess, om enn i ulik styrke i forskjellige læringssituasjoner.

\section{Aktiv læring må engasjere hver enkelt student}

Studentaktive arbeidsformer inneholder læring individuelt og i fellesskap. Freeman og medarbeidere (9) definerer studentaktiv læring slik: «Active learning engages students in the process of learning through activities and/or discussion in class, as opposed to passively listening to an expert. It emphasizes higher-order thinking and often involves group work» (9, s. 4-5).

Fraser og medarbeidere (10) vektlegger at aktiv læring må engasjere hver enkelt student. Sfard (11) uttrykker at man mister noe ved å velge et læringsperspektiv, og snakker om «patches of coherence» (lapper av sammenheng).

\section{«Vi tok utgangspunkt i at læring omfatter både kognitive og sosiale prosesser.»}

Vi tok utgangspunkt i at læring omfatter både kognitive og sosiale prosesser. Begge de læringsteoretiske posisjonene vektlegger at studentene legger inn en egeninnsats og deltar i faglig virksomhet. 


\section{Studentene tilegnet seg temaet ved aktive metoder}

Vi la opp til at studentene skulle tilegne seg temaet gjennom studentaktive metoder. Emnet startet med en timeplanbelagt undervisning hvor vi gikk gjennom emnets oppbygning og gjennomføring. Vi introduserte studentene for læringsstien vi hadde laget i læringsplattformen Canvas.

Denne læringsstien inneholdt ulike måter å innhente teoretiske kunnskaper og ferdigheter på. Studentene måtte gå gjennom én modul (et delemne) før de fikk tilgang til den neste. To av modulene ble lagt ut i form av film.

Her underviste vi først om henholdsvis ufullstendige setninger og metakommunikasjon. Undervisningen fulgte vi opp ved å vise metodene i et rollespill med en påfølgende refleksjon rundt det som skjedde i rollespillet, og bruk av metodene i sykepleiefaget.

I andre moduler måtte studenten lese pensum og PowerPoint-presentasjoner i læringsstien og deretter løse konkrete oppgaver.

\section{Metodeøvelser ble gjennomført i små grupper}

For å støtte opp under studentenes ferdigheter og erfaringslæring delte vi kullet på 140 i fire grupper. Hver gruppe hadde to timer med metodeøvelser. Studentene jobbet sammen i triader, hvor én var sykepleier, én var pasient og én var observatør.

Vi ga dem to forskjellige situasjoner der de skulle veilede henholdsvis en ny beboer på et sykehjem og en mann som skulle mestre sin livssituasjon etter å ha fătt utlagt tarm. Alle studentene fikk prøve seg som veileder i hver situasjon. Vi gikk rundt og veiledet i de små gruppene.

De aller fleste studentene hadde vært inne i læringsstien før de møtte opp til metodeøvelsene. Det var stor forskjell på mestring i de fire gruppene, men vi opplevde at de aller fleste gikk inn i rollespillene.

Noen få studenter greide ikke å komme i gang; de visste ikke hva de skulle si som sykepleier. Læreren viste da hvordan de kunne starte veiledningen, og ba studenten om ta over. De fleste studentene var lydhøre og mottakelige for vår veiledning da vi gikk rundt i gruppene.

Mange studenter fikk viktige aha-opplevelser både i triadene og i en felles refleksjon etter hver situasjon. I veiledningen vår fanget vi opp at mange av studentene gikk fort inn i tiltakene og rådene. Det var også utfordrende å lytte til det pasienten sa, og ta utgangspunkt i dette videre. 


\section{Det var store forskjeller i eksamensbesvarelsene}

Eksamensoppgaven (figur 1) inneholdt alle de aktuelle læringsutbyttene og ble lagt ut i Canvas ved oppstarten av emnet. Sensuren viste store forskjeller. Flere grupper fikk tydelig vist at de hadde forstått de aktuelle metodene, både i rollespillet og samtalen etterpå.

\section{Figur 1. Eksamen}

Oppgaven er en gruppeoppgave med cirka fem studenter i hver gruppe. Den består av både en skriftlig del og å lage en video.

\section{Utgangspunkt for oppgaven}

Rune Olsen er 18 år gammel og innlagt på medisinsk avdeling. Han har nettopp fått påvist diabetes type 1 .

Han går på idrettslinjen i videregående skole og er en aktiv idrettsutøver.

Rune står nå foran en krevende situasjon hvor han skal lære seg å mestre sin nye hverdag.

\section{Oppgaven}

1. Skriftlig del

Planlegg et undervisningsopplegg ut ifra den didaktiske relasjonsmodellen hvor målet er at Rune får det $n \varnothing$ dvendige grunnlaget for å mestre sin nye livssituasjon. Begrunn momentene i opplegget. Maks. antall ord: 1200.

2. Lag en video som viser følgende:

a. Et rollespill fra en veiledningssamtale med Rune. En student spiller henholdsvis Rune og en sykepleier i samtalen. Maks. tre minutter.

b. En samtale blant alle gruppemedlemmene. Denne samtalen følger etter rollespillet, og her deltar alle i gruppen. I denne samtalen skal studentene begrunne hvilke prinsipper/metoder som ligger til grunn i veiledningssamtalen. Maks. ti minutter.

En gjennomgående utfordring i rollespillet var at sykepleieren ga råd fort og ikke mestret å lytte aktivt til det pasienten var opptatt av. Noen grupper viste større forståelse i samtalen enn i selve rollespillet. Noen få gjennomførte ikke samtale, men leste opp fra et ferdig manus.

Etter eksamen hadde vi en gjennomgang i stor klasse. Her løftet lærerne frem hva studentene hadde mestret når det gjaldt læringsutbyttene.

Lærerne tok opp gjennomgående utfordringer i besvarelsene, som skillet mellom undervisning og veiledning, hva aktiv lytting innebærer, og hvordan man kan unngå å falle for fristelsen til å gi råd og iverksette tiltak før man har unders $\varnothing \mathrm{kt}$ nærmere hva pasienten er opptatt av.

Videoen til gruppen som hadde best mestring, ble vist i plenum for å gi studentene mulighet til å speile sitt eget bidrag. For å bevisstgjøre studentene på deres egen læring ba vi dem om å skrive ned tre ting de hadde lært om den pedagogiske og veiledende funksjonen (figur 2). 
Figur 2. Eksempel på hva studentene lærte i emnet

\begin{tabular}{|l|}
\hline Forskjell på veiledning og undervisning, at alle pasienter er ulike og trenger ulik tilnærming \\
\hline Hvordan forsterke empowerment? \\
\hline Å tenke bedre over hvordan jeg kommuniserer, å være en bedre lytter, stille oppfølgende spørsmål og vente på svar \\
\hline God kommunikasjon, veiledende fremgangsmåte, forskjellen på åpne og lukkede spørsmål \\
\hline Ulike veiledningsmetoder \\
\hline
\end{tabular}

\section{Studentene evaluerte emnet}

Totalt 78 prosent av studentene sa at de var motivert for studieinnsats. Flere studenter (59 prosent) var enig i at metode øvelsene i større grad enn arbeidet og undervisningsformene i Canvas (42 prosent) bidro til å oppnå læringsutbyttet.

Hele 84,5 prosent av studentene var enig $i$ at de hadde et godt samarbeid $i$ smågruppene og eksamensgruppen. Av studentene var det 70 prosent som opplevde at deres egen studieinnsats var høy.

Bare 27 prosent av studentene var fornøyd med undervisningsopplegget som helhet, mens 48 prosent var uenig i dette. Likevel var vel 80 prosent enig i at emnet hadde gitt dem en viss forstålse for sykepleierens pedagogiske og veiledende funksjon.

Tilbakemeldingen etter endt undervisning bekreftet at studentene blant annet hadde lært forskjellen på undervisning og veiledning og betydningen av brukermedvirkning.

Flere kommentarer i evalueringsskjemaet dreide seg om et ønske om mer undervisning. Kommentarene viste at studentene var fornøyd med det sosiale miljøet og samarbeidet i smågruppene og eksamensgruppen. Samtidig var det mange kommentarer om ujevn deltakelse i arbeidet med eksamen.

\section{Metodeøvelsene var mest betydningsfulle for studentene}

Ved at studentene jobbet individuelt i læringsstien, la vi til rette for at deres kognitive og følelsesmessige perspektiv skulle bli stimulert. Individuell jobbing gjennom læringsstien skulle gi gode forutsetninger for aktiviteten i smågruppene og eksamensgruppen. 
Langt flere studenter var enig i at metodeøvelsene i større grad enn læringsstien bidro til læringsutbytte. En mulig årsak kan være at studentene ikke ble motivert av læringsstien, og dermed heller ikke utnyttet potensialet i dette opplegget, som primært stimulerte det kognitive og følelsesmessige aspektet.

\section{«Langt flere studenter var enig $i$ at metodeøvelsene $i$ større grad enn læringsstien bidro til læringsutbytte.»}

I kommentarfeltet i evalueringsskjemaet etterspurte studentene mer undervisning. Tradisjonell undervisning stimulerer den kognitive dimensjonen. I vårt opplegg blir den kognitive dimensjonen stimulert i en form som krever større egeninnsats enn $i$ tradisjonell undervisning.

Det kan være en annen årsak til at læringsstien kom dårligere ut enn metodeøvelsene. I henhold til Illeris (8) evaluerer studentene samspillsprosessen høyere enn individets tilegnelsesprosess. Dersom vi ser på innholdsdimensjonen, viser tilbakemeldingene fra studentene at vi traff med situasjonene i metodeøvelsene.

\section{Studentene var motivert for studieinnsats}

Evalueringen av innholdsdimensjonen i læringsstien er ikke like entydig. Flertallet av studentene mente at dette var godt, mens noen $\varnothing$ nsket mer innhold. Evalueringen viste at samspillsdimensjonen var god, men samtidig sa flere studenter at det var ujevn deltakelse i arbeidet med eksamen. Det vitner om en spenning i denne dimensjonen.

Flere momenter i evalueringen viser at studentene hadde en positiv drivkraft $\mathrm{i}$ emnet. De var i stor grad motivert for studieinnsats, hadde et godt samarbeid og opplevde at de hadde høy egeninnsats.

Dette viser at Illeris' (8) to prosesser og tre dimensjoner inngår i ulik styrke i studentenes læreprosess. Et aktuelt spørsmål for oss er om noen av prosessene eller dimensjonene skulle vært styrket i vårt opplegg.

Dersom studentene møtte til emnet og forventet tradisjonell undervisning, skulle vi i større grad ha rammet inn den pedagogiske tenkningen bak opplegget for å hjelpe dem til å finne både mening og motivasjon i opplegget og dermed $\varnothing \mathrm{ke}$ drivkraftdimensjonen. Vi vil derfor bruke mer tid på den timeplanbelagte introduksjonen neste gang. 


\section{Studentene ble bevisst på sine egne ferdigheter}

Det at studentene løfter frem metodeøvelsene som mest betydningsfullt for sitt læringsutbytte, er i tråd med tenkningen bak konfluent pedagogikk. Øvelsene tilrettela for at studentene kunne gjøre oppdagelser når det gjaldt hva veiledning er, samt deres egne følelser og kroppsreaksjoner (5).

Studentenes evaluering stemmer overens med vår opplevelse under metodeøvelsene. Mange gjorde seg viktige aha-oppdagelser, og alle studentene ble utfordret på sine egne følelser og kroppsreaksjoner i veilederrollen.

Det å bli bevisst på sine egne ferdigheter vil være viktig for den videre læringen i veilederrollen. Mange studenter oppdaget også at de hadde for lite teoretisk kunnskap til å være trygge i rollen. Det viser at både «knowing how» og «knowing that» (3) er sentralt for deres utøvelse.

Ved å stimulere både teoretisk og praktisk kunnskap innenfor et undervisningsopplegg kan studentene motiveres til å innhente den kunnskapen de oppdager at er mangelfull.

\section{Mange viste kroppslig uro i rollespillet og samtalen}

Vi fanget opp at mange studenter viste kroppslig uro i rollespillet og i samtalen etterpå. Eksamensformen utfordret naturligvis studentene, men vi mener likevel at vi fanget opp en usikkerhet knyttet til personlig og faglig utrygghet.

\section{«Vårt opplegg er et eksempel på hvordan ferdighetstrening og erfaringslæring også kan vektlegges i teori.»}

Et interessant spørsmål blir da i hvilken grad vi i utdanningen tilrettelegger for at studentene kan nå en faglig og personlig trygghet. Tradisjonelt i utdanningen blir det kognitive aspektet stimulert gjennom teori, mens erfaringslæring blir mest vektlagt i kliniske studier.

Med støtte i Grenstad (5), Freeman og medarbeidere (9) og Grimen (4) vil vi hevde at vi i større grad skulle vektlagt erfaringslæring og oppdagelse av følelser og kroppsreaksjoner i møte med ulike temaer også i teori, for på den måten gi dem større grad av både faglig og personlig trygghet.

Vårt opplegg er et eksempel på hvordan ferdighetstrening og erfaringslæring også kan vektlegges i teori. 


\section{Studentene lærte av opplegget, men likte det ikke}

Evalueringen viser en motsigelse ved at studentene i liten grad var fornøyd med undervisningsopplegget som helhet, samtidig som de oppga å ha fått stort utbytte i form av begynnende forståelse for sykepleierens pedagogiske og veiledende funksjon.

Studentene har med andre ord lært, men ikke likt, opplegget. Studentaktive læringsmetoder engasjerer hver enkelt student (10). Dette engasjementet utfordrer studenten og står i kontrast til en mer passiv mottakersituasjon, som er karakteristisk i en tradisjonell formidlingssituasjon.

For å sikre læringen utfordret vi studentene i vårt opplegg ved å bruke flere læringsperspektiv, som Sfad (11) omtaler som lapper av sammenheng

\section{Konklusjon}

En av sykepleierens sentrale funksjoner er den pedagogiske og veiledende funksjonen. Denne funksjonen krever teoretisk kunnskap, men også ferdigheter i og bevissthet om sin egen rolle.

Vi har skissert et studentaktivt opplegg for dette emnet i sykepleierutdanningen. Her tilrettela vi for studentenes læring både individuelt og i fellesskap og stimulerte både kognitive, følelsesmessige og psykomotoriske aspekter.

Evalueringen viser at emnet i stor grad ga studentene læringsutbytte i form av en begynnende forståelse for sykepleierens pedagogiske og veiledende funksjon, men samtidig var de i liten grad fornøyd med opplegget som helhet.

Studentaktive læringsformer utfordrer studentene, noe vi som lærere må tåle å stå i. Samtidig er det viktig å bruke studentenes tilbakemeldinger for å videreutvikle opplegget.

For vår del handler det i første omgang om å styrke studentenes drivkraftdimensjon ved i større grad å ramme inn den pedagogiske tenkningen bak opplegget.

\section{Referanser}

1. Verdens helseorganisasjon (WHO). Ottawa charter for health promotion: an International Conference on Health Promotion, the move towards a new public health 17-21 November 1986. Genève: WHO; 1986. 
2. Forskrift 15. mars 2019 nr. 412 om nasjonal retningslinje for sykepleierutdanning. Tilgjengelig fra:

https://lovdata.no/dokument/SF/forskrift/2019-03-15-412 (nedlastet 10.10.2021).

3. Ryle G. The concept of mind. Chicago: Chicago University Press; 1949.

4. Grimen H. Profesjonsstudier. Oslo: Universitetsforlaget; 2008.

5. Grenstad NM, Sandven GJ. Å lære er å oppdage. Prinsipper og praktiske arbeidsmåter i konfluent pedagogikk. Kongsberg: Didakta; 1986.

6. Hatlevik IKR, Havnes A. Perspektiver på læring i profesjonsutdanninger fruktbare spenninger og meningsfulle sammenhenger. I: Mausethagen S, Smeby JC, red. Kvalifisering til profesjonell yrkesutøvelse. Oslo: Universitetsforlaget; 2017. s. 191-203.

7. Illeris KA. Comprehensive understanding of human learning. I: K. Illeris, red. Contemporary theories of learning. London/New York: Routledge; 2009. s. 7-20.

8. Illeris K. Læring. Oslo: Gyldendal Akademisk; 2012.

9. Freeman S, Eddy SL, McDonough M, Smith MK, Okoroafor N, Jordt H, et al. Active learning increases student performance in science, engineering, and mathematics. 2014;111(23):8410-5. DOI: 10.1073/pnas.1319030111

10. Fraser JM, Timan AL, Miller K, Dowd JE, Tucker L, Mazur E. Teaching and physics education research: bridging the gap. Reports on Progress in Physics. 2014;77(3):032401. DOI: 10.1088/0034-4885/77/3/032401

11. Sfard A. On two metaphors for learning and the dangers of choosing just one. Educational researcher. 1998 mars;27(2):4-13. DOI: 10.2307/1176193 